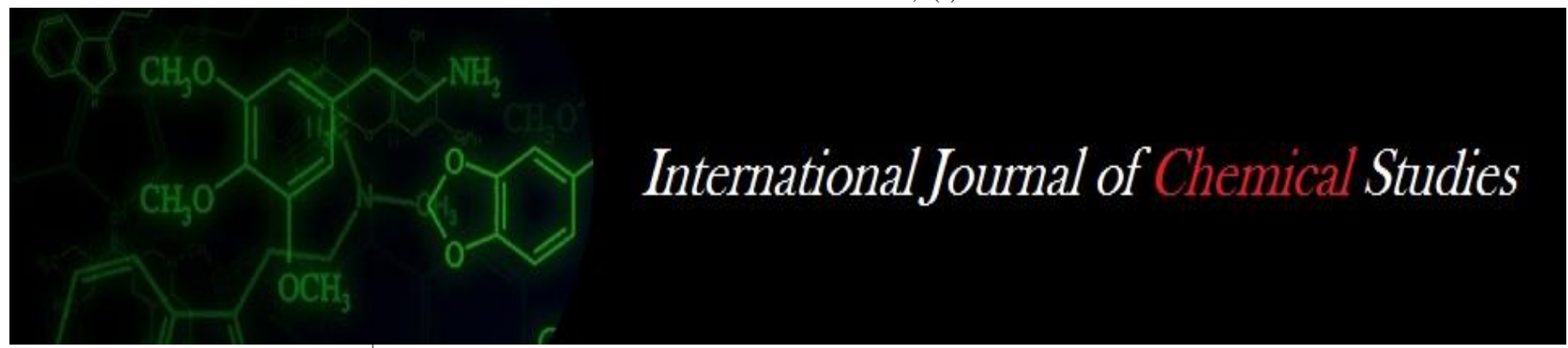

P-ISSN: 2349-8528

E-ISSN: 2321-4902

www.chemijournal.com

IJCS 2020; 8(4): 2252-2253

(C) 2020 IJCS

Received: 13-05-2020

Accepted: 15-06-2020

Kolse Ravindra

Assistant Professor of

Agronomy, Mahatma Phule

Krishi Vidyapeeth, Rahuri,

Maharashtra, India

Ashutosh Dhonde

Senior Research fellow of

Agronomy, Mahatma Phule

Krishi Vidyapeeth, Rahuri,

Maharashtra, India

Sunil Thorat

Research Associate of

Agronomy, Mahatma Phule

Krishi Vidyapeeth, Rahuri,

Maharashtra, India
Corresponding Author: Kolse Ravindra

Assistant Professor of

Agronomy, Mahatma Phule

Krishi Vidyapeeth, Rahuri,

Maharashtra, India

\section{Effect of different irrigation regimes and fertigation levels on water requirement of turmeric}

\author{
Kolse Ravindra, Ashutosh Dhonde and Sunil Thorat
}

DOI: https://doi.org/10.22271/chemi.2020.v8.i4y.9963

\section{Abstract}

The agronomic investigation entitled, "Effect of irrigation regimes and fertigation levels on yield, quality and soil properties of turmeric (Curcuma longa L.) was undertaken during 2012-13 and 2013-14 on clay loam soil at Irrigation Water Management Project, Mahatma Phule Krishi Vidyapeeth, Rahuri. The irrigation regimes drip irrigation at $0.5 \mathrm{ETc}$ was recorded maximum water use efficiency as well as higher water saving followed by irrigation regimes drip irrigation at 0.7 ET than rest of treatments.

Keywords: Turmeric, yield, irrigation, regimes, water use efficiency

\section{Introduction}

Turmeric (Curcuma longa L), the ancient and sacred spice of India known as 'Indian saffron' is an important commercial spice crop grown in India. It is used in diversified forms as a condiment, flavoring and coloring agent and as a principal ingredient in Indian culinary as curry powder. It has anti cancer and anti viral activities and hence finds use in the drug industry and cosmetic industry. 'Kum-kum', popular with every house wife, is also a byproduct of turmeric. It finds a place in offerings on religious and ceremonial occasions. A type of starch is also being extracted from a particular type of turmeric. The increasing demand for natural products as food additives makes turmeric as ideal produce as a food colorant. Turmeric is the dried rhizome of Curcuma longa (L.), a herbaceous perennial belonging to the family Zingiberaceae and a native of South Asia particularly India. India is the largest producer, consumer and exporter of turmeric in the world. The global production of turmeric is around 11 lakh tones per annum.

India dominates the world production scenario contributing $78 \%$ followed by China $(8 \%)$, Myanmar (4\%) and Nigeria and Bangala Desh together contributing to $6 \%$ of the global production. India is the global leader in value added products of turmeric and exports. Other major exporters are Thailand, other Southeast Asian countries, Central and Latin America and Taiwan. United Arab Emirates (UAE) is the major importer of turmeric from India accounting for $18 \%$ of the total exports followed by United States of America (USA) with $8 \%$. The other leading importers are Bangladesh, Japan, Sri Lanka, United Kingdom, Malaysia, South Africa, Netherland and Saudi Arabia. All these countries together account for $75 \%$ of the world imports and Asian countries are the main suppliers to the entire world. The remaining $25 \%$ is met by Europe, North America and Central and Latin American countries. United States of America imports $97 \%$ of its turmeric requirement from India and the remaining portion from the Islands of the Pacific and Thailand. Out of the total global production UAE accounts for $18 \%$ of the imports, followed by USA (11\%), Japan (9\%), Srilanka, United Kingdom, Malaysia together accounting for $17 \%$.

Water is the vital source for crop production and is the most limiting factor in Indian agricultural scenario. Though India has the largest irrigation network, the irrigation efficiency has not been achieved more than $40 \%$. The per capita water availability, in terms of average utilizable water resources in the country, has dropped from $6008 \mathrm{M}^{3}$ in 1947 to $1250 \mathrm{M}^{3}$ now and is expected to dwindle down to $760 \mathrm{M}^{3}$ (Singh, 2006). There are $140 \mathrm{~m}$ ha of arable land in India of which $41.2 \mathrm{~m}$ ha are being irrigated (Ramah, 2008) ${ }^{[3]}$. 
In India, the potential for the drip irrigation system is estimated to be $21.27 \mathrm{~m}$ ha (Narayanamoorthy, 2008) ${ }^{[2]}$. Water saving from drip irrigation system varied from 12 to $84 \%$ for different crops besides increasing the production of crops. Maharashtra and Tamil Nadu are the leading states using drip. However, it is observed that the research work on irrigation and fertigation in turmeric in India in general and Maharashtra in particular is limited. In view of this, it was proposed to conduct an experiment on effect of irrigation regimes and fertigation on yield, quality and soil properties of turmeric

\section{Material and Methods}

The experiment was laid out in split plot design with three replications and nineteen treatment combinations comprising of three irrigation regimes viz., at $0.5 \mathrm{ET}_{\mathrm{C}}, 0.7 \mathrm{ET}_{\mathrm{C}}, 0.9 \mathrm{ET}_{\mathrm{C}}$ drip, and six fertilizer levels viz., 100 per cent general recommended dose of water soluble fertilizer through conventional fertilizer, 100 per cent general recommended dose of water soluble fertilizer - $\mathrm{P}$ and $\mathrm{K}$ basal conventional and $\mathrm{N}$ through drip, 100 per cent general recommended dose of water soluble fertilizer through drip, 75 per cent general recommended dose of water soluble fertilizer through drip, 50 per cent general recommended dose of water soluble fertilizer through drip.

\section{Result and Discussion \\ Water use \\ Water requirement}

The data on total water applied, water use efficiency and water saving are depicted in Tables 1.

\section{Effect of irrigation regimes}

The data from Table 1 revealed that during first season of experimentation 2012-13. The total water requirement of turmeric under surface irrigation was $183.5 \mathrm{~cm}$ which was more than rest of the irrigation regimes; minimum water applied was noticed in irrigation regime $0.5 \mathrm{ET}_{\mathrm{C}} 39.23 \mathrm{~cm}$ throughout the crop growth period during first season of experimentation 2012-13. During second season (2013-14 Table 1) the total water requirement of turmeric under surface irrigation was $148.7 \mathrm{~cm}$, which was more than rest of the irrigation regimes; minimum water requirement was noticed in irrigation regime at $0.5 \mathrm{ET}_{\mathrm{C}} 27.66 \mathrm{~cm}$ throughout the crop growth period.

Irrigation water saving due to drip irrigation compared to surface irrigation ranged from 61.51 to 78.62 per cent during first season $2012-13$ and 66.50 to 81.39 per cent during second season 2013-14. The maximum field water use efficiency was obtained under irrigation scheduling at $0.5 \mathrm{ET}_{\mathrm{C}}$ $\left(114.93 \mathrm{~kg} \mathrm{ha}^{-1} \mathrm{~cm}\right)$ followed by treatment irrigation regime 0.7 and $0.9 \mathrm{ET}_{\mathrm{C}}\left(88.91\right.$ and $\left.71.76 \mathrm{~kg} \mathrm{ha}^{-1}\right)$ during 2012-13. During 2013-14 maximum field water use efficiency was obtained under irrigation regime 0.5 ETC $\left(210.88 \mathrm{~kg} \mathrm{ha} \mathrm{cm}^{-1}\right)$ followed by irrigation regime 0.7 and 0.9 ETC (162.92 and $134.86 \mathrm{~kg} \mathrm{ha}^{-1} \mathrm{~cm}$ ) respectively.

\section{Effect of fertigation levels}

The maximum water use efficiency was achieved by application of 100 per cent general recommended dose of water soluble fertilizer through drip irrigation 73.62 and $182.91 \mathrm{~kg} \mathrm{ha}^{-1} \mathrm{~cm}$ respectively during 2012-13 and 2013-14, followed by 75 per cent general recommended dose of water soluble fertilizer through drip irrigation. It might be due to more yield and minimum water requirement for production of 1 quintal of rhizome, followed by 75 per cent general recommended dose of water soluble fertilizer through drip irrigation. The above results are in confirmation with of Kadam and Karthikeyan (2006) ${ }^{[1]}$.

Table 1: Water applied and water use efficiency for turmeric crop as influenced by irrigation regimes and fertigation levels

\begin{tabular}{|c|c|c|c|c|c|c|c|c|c|c|c|c|c|}
\hline \multirow{2}{*}{\multicolumn{2}{|c|}{ Treatment }} & \multicolumn{2}{|c|}{\begin{tabular}{|c|} 
Dry rhizome yield \\
$\left(\mathrm{kg} \mathrm{ha}^{-1}\right)$
\end{tabular}} & \multicolumn{2}{|c|}{$\begin{array}{c}\text { Water applied } \\
(\mathrm{cm})\end{array}$} & \multicolumn{2}{|c|}{\begin{tabular}{|c|} 
Effective rainfall \\
$(\mathrm{cm})$
\end{tabular}} & \multicolumn{2}{|c|}{$\begin{array}{c}\text { Total water } \\
\text { applied }(\mathrm{cm})\end{array}$} & \multicolumn{2}{|c|}{$\begin{array}{c}\text { Water use efficiency } \\
\left(\mathrm{kg} \mathrm{ha}^{-1} \mathbf{~ c m}\right)\end{array}$} & \multicolumn{2}{|c|}{$\begin{array}{c}\text { Water saving } \\
(\%)\end{array}$} \\
\hline & & 2012-13 & 2013-14 & $2012-13$ & 2013-1 & $2012-13$ & 2013-14 & $2012-13$ & 2013- & 2012-13 & 2013-14 & $2012-13$ & 2013- \\
\hline A. & \multicolumn{13}{|c|}{ Irrigation regimes } \\
\hline$I_{1}:$ & Drip irrigation at $0.5 \mathrm{ETc}$ & 4509 & 5833 & 32.53 & 21.41 & 6.7 & 6.26 & 39.23 & 27.66 & 114.93 & 210.88 & 78.62 & 81.39 \\
\hline$I_{2}:$ & Drip irrigation at $0.7 \mathrm{ETc}$ & 4877 & 6310 & 45.55 & 29.97 & 9.3 & 8.77 & 54.85 & 38.73 & 88.91 & 162.92 & 70.10 & 73.95 \\
\hline $\mathrm{I}_{3}:$ & Drip irrigation at $0.9 \mathrm{ETc}$ & 5068 & 6716 & 58.56 & 38.53 & 12.06 & 11.27 & 70.62 & 49.8 & 71.76 & 134.86 & 61.51 & 66.5 \\
\hline B. & \multicolumn{13}{|c|}{$\begin{array}{l}\text { Fertigation levels } \\
\end{array}$} \\
\hline $\mathrm{F}_{1}$ : & $\begin{array}{c}100 \% \text { GRDF -Conventional } \\
\text { fertilizer }\end{array}$ & 4761 & 6478 & 45.55 & 29.97 & 9.3 & 8.77 & 54.85 & 38.73 & 86.80 & 167.26 & - & - \\
\hline $\mathrm{F}_{2}:$ & $\begin{array}{c}100 \% \text { GRDF }-\mathrm{P} \text { and } \mathrm{K} \text { basal } \\
\text { C.F \& N through drip }\end{array}$ & 4858 & 6682 & 45.55 & 29.97 & 9.3 & 8.77 & 54.85 & 38.73 & 88.56 & 172.53 & - & - \\
\hline $\mathrm{F}_{3}:$ & $100 \%$ GRDF - through W.S.F. & 5686 & 7084 & 45.55 & 29.97 & 9.3 & 8.77 & 54.85 & 38.73 & 103.66 & 182.91 & - & - \\
\hline $\mathrm{F}_{4}:$ & $75 \%$ GRDF - through W.S.F. & 5558 & 6924 & 45.55 & 29.97 & 9.3 & 8.77 & 54.85 & 38.73 & 101.33 & 178.78 & - & - \\
\hline $\mathrm{F}_{5}$ : & $50 \%$ GRDF - through W.S.F & 4598 & 6100 & 45.55 & 29.97 & 9.3 & 8.77 & 54.85 & 38.73 & 83.82 & 157.50 & - & - \\
\hline $\mathrm{F}_{6}:$ & No fertilizers & 3447 & 4449 & 45.55 & 29.97 & 9.3 & 8.77 & 54.85 & 38.73 & 62.84 & 114.87 & - & - \\
\hline & Surface irrigation-control & 4089 & 5864 & 156 & 120 & 27.5 & 28.7 & 183.5 & 148.7 & 22.28 & 39.44 & - & - \\
\hline
\end{tabular}

\section{Conclusion}

It was concluded that, irrigation regimes drip irrigation at 0.5 ETc was recorded maximum water use efficiency as well as higher water saving followed by irrigation regimes drip irrigation at 0.7 ETc however, 100 per cent general recommended dose of water soluble fertilizer through drip irrigation recorded maximum water use efficiency.

\section{Reference}

1. Kadam JR, Karthikeyan S. Effect of soluble NPK fertilizers on the nutrient balance, water use efficiency, fertilizer use efficiency of drip system in a Tomato. International Journal of Plant Sci. 2006; 1(1):92-94.

2. Narayanamoorthy A. Drip irrigation in India: can it solve water scarcity? Water Policy. 2008; 6:117-130.

3. Ramah K. Study on Drip Fertigation in maize based cropping system. PhD Thesis, Tamil Nadu Agricultural University, Coimbator, 2008. 